\title{
Drug Resistance and Transferable R Plasmids in Edwardsiella tarda from Fish Culture Ponds
}

\author{
Takashi AOKI and Tadatoshi KITAO \\ Department of Fisheries, Faculty of Agriculture, Miyazaki University, \\ Miyazaki 880, Japan
}

\begin{abstract}
One hundred sixty eight strains of Edwardsiella tarda collected from cultured eel (Anguilla japonica), tilapia (Tilapia nilotica) and channel catfish (Ictalurus punctatus), and from water and plankton of culture ponds were studied for their sensitivities to 10 chemotherapeutic agents: chloramphenicol (CM), tetracycline (TC), streptomycin (SM), kanamycin (KM), aminobenzyl penicillin (ABP), cefazolin (CEZ), nalidixic acid (NA), furazolidone (NF), sulfamonomethoxine (SA) and trimethoprim (TMP). All strains were highly sensitive to CEZ and TMP. Only 32 of 168 strains were sensitive to all the drugs tested. The remaining 136 strains were resistance to various combinations of the 8 drugs (CM, TC, SM, KM, ABP, NA, NF and/or SA). The most common types of drugs resistance were to combinations of CM, TC, NF and/or SA.

Transferable $\mathrm{R}$ plasmids were detected in 38 out of 136 resistant strains. The most common type of resistance markers of $\mathrm{R}$ plasmid was $\mathrm{CM}, \mathrm{TC}$ and $\mathrm{SA}$. Other $\mathrm{R}$ plasmids had markers for resistance to TC, SA, TC SA and CM TC SM KM SA.

Cryptic plasmids weré also detected in all strains $E$. tarda tested by agarose gel electrophoresis.
\end{abstract}

Eel culture is the most popular of all freshwater fish culture in Japan. The annual production reached about 32,000 tons in 1978 . In recently years, eel culture has been carried out in closed systems in warm water ponds enclosed in green houses. Consequently, eel culturists are now able to expect short term culture and high production. They usually keep as many fish as possible in a limited pond space in order to increase productivity per unit space. This naturally causes unfavourable conditions for cultured fish, and incidences of bacterial infections, such as edwardsiellosis have been frequent (WAKABAYASHI and EgUSA, 1973). Under warm water conditions, edwardsiellosis can occur in both adult and young eel throughout the year (MryazaKi and Egusa, 1976). Accordingly, antibitotics and synthetic chemotherapeutics have been used for the treatment of edwardsiellosis. The application of chemotherapeutics to eel ponds have caused the increase of drug resistant strains of Edwardsiella tarda and transferable $\mathrm{R}$ plasmids have been detected (AOKI et al., 1977). As a result, chemotherapy of edwardsiellosis has become very difficult, and high levels of various chemotherapeutics have been introduced in eel culture.
Edwardsiellosis has been seen not only in cultured eel but also for other cultured freshwater fish; channel catfish (Ictalurus punctatus) (MEYER and Bullock, 1973), large mouth bass (Micropterus salmoides) (WHITE et al., 1973) and tilapia (Tilapia nilotica) (unpublished data), as well as for marine fish; mullets (Mungil cephalus) (KusUdA et al., 1976) and sea bream (Evynnis japonicus) (Kusuda et al.).

In this study, strains of E. tarda colleted from fish culture ponds were tested for their susceptibilities to selected drugs. Drug resistant strains detected were further studied for the presence of transferable $\mathbf{R}$ plasmids.

Crosa et al. (1977) reported that a high virulent phenotype of the bacterial fish pathogen, Vibrio anguillarum is correlated with their specific plasmid. We also tried to detect cryptic other than $\mathbf{R}$ plasmids in our strains of $E$. tarda by assaying their plasmid DNAs by agarose electrophoresis.

\section{Meterials and Methods}

One hundred sixty eight strains of Edwardsiella tarda were collected from cultured eel, tilapia and channel catfish and from culture pond water and 
Table 1. Sources of strains of Edwardsiella tarda

\begin{tabular}{|c|c|c|c|c|c|c|c|c|}
\hline \multirow{2}{*}{ Area } & \multicolumn{8}{|c|}{ Year } \\
\hline & 1972 & 1973 & 1975 & 1976 & 1977 & 1978 & 1979 & Total \\
\hline Shizuoka & 29 & 1 & & 58 & & & & 88 \\
\hline Aichi & & & & & & & 3 & 3 \\
\hline Tokushima & & & & 3 & 9 & 21 & & 33 \\
\hline Nagasaki & & & & & 4 & & 2 & 6 \\
\hline Ooita & & & & & & 2 & & 2 \\
\hline Kagoshima & & & & & & 4 & 3 & 7 \\
\hline Miyazaki & & & 1 & & 2 & 9 & 2 & 14 \\
\hline Okinawa & & & & & & & 2 & 2 \\
\hline Taiwan & & & & 2 & 10 & & & 12 \\
\hline USA & & 1 & & & & & & 1 \\
\hline Total & 29 & 2 & 1 & 63 & 25 & 36 & 12 & 168 \\
\hline
\end{tabular}

plankton (Table 1). The strains were tested for their sensitivities to various chemotherapeutic agents. The serial, two-fold dilution method in agar medium recommended by the Japan Society of Chemotherapy (1975) for determination of the minimal inhibitory concentrations (MICs) of various drugs, was followed. The incubation temperature used was $30^{\circ} \mathrm{C}$.

The chemotherapeutics used were chloramphenicol (Sankyo) (CM), tetracycline hydrochloride (Lederle) (TC), streptomycin sulphate (Meiji) (SM), kanamycin sulphate (Meiji) (KM), aminobenzyl penicillin (Fujisawa) (ABP), cefazolin (Fujisawa) (CEZ), nalidixic acid (Daiichi) (NA), furazolidone (Takeda) (NF), sulfamonomethoxine (Daiichi) (SA) and trimethoprim (Takeda) (TMP).

Penassay broth (Difco) was used as the medium for pre-culture and Heart infusion agar (Nissui) was used as the medium for sensitivity tests to antibiotics, NA and NF. Sensitivity disc medium (modified Mueller-Hinton agar) (Nissui) was used to test sensitivity to SA and TMP.

Each drug resistant strain of $E$. tarda was incubated in penassay broth with aeration at $30^{\circ} \mathrm{C}$ to about $5 \times 10^{8}$ cells $/ \mathrm{ml}$. Escherichia coli $\mathrm{RC} 85$ nal (nalidixic acid resistant) was incubated in penassay broth with aeration at $37^{\circ} \mathrm{C}$ to an equal density. One $\mathrm{m} l$ of $E$. tarda culture was mixed with $1 \mathrm{~m} l$ of $E$. coli $\mathrm{RC} 85$ in a test tube, incubated overnight at $37^{\circ} \mathrm{C}$, and then plated on BTBlactose nutrient agar (WATANABE et al., 1971) containing NA and each one of the drugs to which the E. tarda strain was resistant. However, NA resistant strains were mixed with $E$. coli W3102 str (streptomycin resistant) instead of RC85. Each of the clones of $\mathrm{RC} 85$ which received a drug resistance plasmid was reisolated for purification on a similar selective medium. The purified clones were then tested for their resistance to unselected drugs by their MICs.

Eleven strains were selected at random from the collection of naturally occurring $E$. tarda strains. Each strain was incubated at $30^{\circ} \mathrm{C}$ in penassay broth to about $5 \times 10^{8}$ cells $/ \mathrm{m} l$. Thirty $\mathrm{m} l$ of each culture was washed by centrifugation and resuspended in $0.2 \mathrm{ml}$ of a Tris-sucrose-EDTA buffer. The cell suspension was lysed by adding $20 \mu \mathrm{l}$ of a $10 \%$ sodium dodecyl sulfate solution, and a clear supernatant was obtained after centrifugation for $20 \mathrm{~min}$ at $18,000 \mathrm{rpm}$ at $5^{\circ} \mathrm{C}$. Aliquots of $10 \sim 40 \mu l$ of supernatant (cleared lysate) of each preparation and standard DNA of Col K (KUNIGATA and MATsuHAshI, 1970) were electrophoresed in $0.8 \%$ agarose gels.

\section{Results}

The distribution of MICs of 10 chemotherapeutic agents against 168 strains of $E$. tarda are shown in Fig. 1. The strains were classified into apparently discrete groups which were sensitive or resistant to $\mathrm{CM}$ as determined by their MICs of about $0.8 \mu \mathrm{g} / \mathrm{m} l$ and $50 \mu \mathrm{g} / \mathrm{ml}$, respectively. The pattern of MICs of TC resistance also gave two groups, 96 sensitive and 72 resistant strains. As for SM, KM, and ABP, the strains were also 

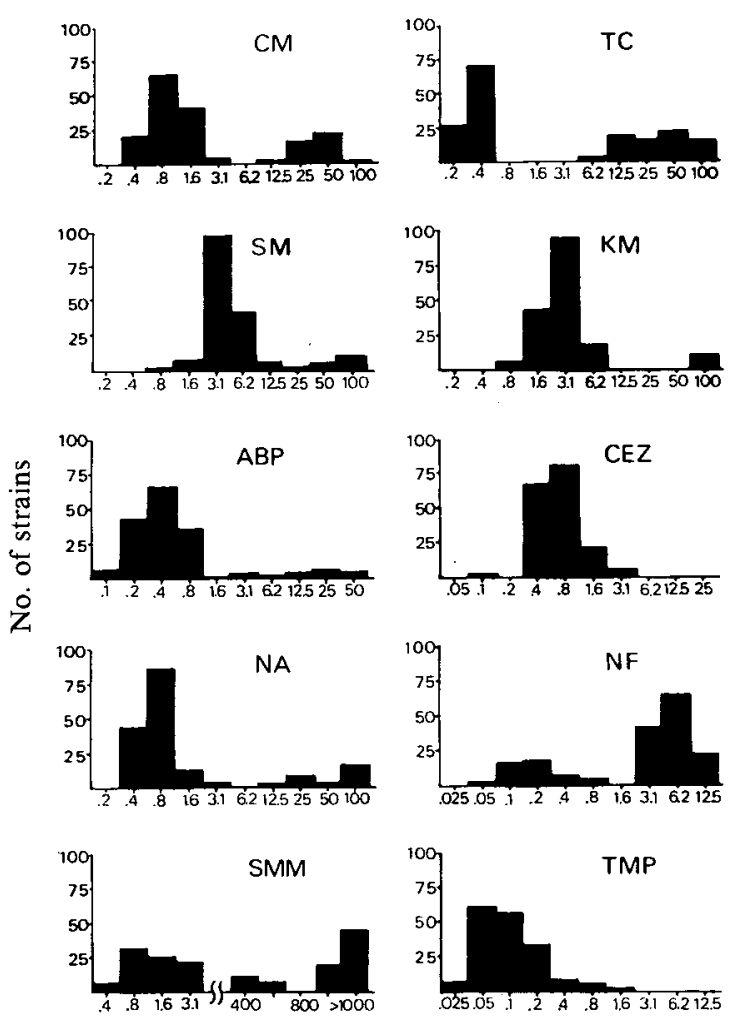

$\operatorname{MIC}(\mu \mathrm{g} / \mathrm{ml})$

Fig. 1. Number of naturally occurring Edwardsiella tarda strains with $\mathrm{MICs}(\mu \mathrm{g} / \mathrm{m} l)$.

Abbreviations: CM, chloramphenicol; TC, tetracycline; SM, streptomycin; KM, kanamycin; ABP, aminobenzyl penicillin; CEZ, cefazolin; NA, nalidixic acid; NF, furazolidone; SMM, sulfamonomethoxine; TMP, trimethoprim.

classified into two apparent groups and showed the presence of some resistant strains for these drugs. Interestingly enough, all strains tested were highly sensitive to CEZ.

Twentyfive strains were found to be resistant to NA. Only 43 of 168 strains were sensitive to NF. As for SA, the strains also fell into two groups, 82 strains were resistant to SA. The MIC of TMP against the strains was from 0.025 to $1.6 \mu \mathrm{g} / \mathrm{m} l$. All strains were highly sensitive to TMP.

Thirtytwo of 168 strains were found to be sensitive to all drugs tested. While the remaining 136 strains were resistance to various combinations of the 8 drugs (Table 2). Of the 136 strains, 45 were
Table 2. Resistance markers and transferable $\mathrm{R}$ plasmids of Edwardsiella tarda isolated from freshwater fish culture ponds

\begin{tabular}{|c|c|c|}
\hline $\begin{array}{l}\text { Resistance marker } \\
\text { of original strain }\end{array}$ & $\begin{array}{c}\mathbf{R}^{+} \\
\text {strains/ } \\
\text { Strains } \\
\text { studied }\end{array}$ & $\begin{array}{l}\text { Resistance marker } \\
\text { of } R \text { plasmid }\end{array}$ \\
\hline Sensitive strains & 32 & \\
\hline $\mathrm{NA}^{\mathrm{a}}$ & $0 / 1$ & \\
\hline NF & $0 / 40$ & \\
\hline SA & $0 / 2$ & \\
\hline TC NF & $0 / 3$ & \\
\hline TC SA & $0 / 2$ & \\
\hline KM NF & $0 / 2$ & \\
\hline $\mathrm{ABP} N \mathrm{NF}$ & $0 / 2$ & \\
\hline NA NF & $0 / 3$ & \\
\hline NF SA & $3 / 9$ & SA \\
\hline CM TC SA & $0 / 2$ & \\
\hline TC NA NF & $1 / 1$ & $\mathrm{TC}$ \\
\hline TC NA SA & $3 / 5$ & TC SA \\
\hline TC NF SA & $4 / 9$ & TC SA \\
\hline KM NF SA & $0 / 1$ & \\
\hline CM TC SM NF & $0 / 1$ & \\
\hline CM TC NA SA & $0 / 1$ & \\
\hline CM TC NF SA & $13 / 14$ & $\begin{array}{l}\text { TC SA (2), } \\
\text { CM TC SA (11) }\end{array}$ \\
\hline CM NA NF SA & $0 / 1$ & \\
\hline TC SM NA NF & $0 / 1$ & \\
\hline TC SM NF SA & $0 / 4$ & \\
\hline TC ABP NF SA & $0 / 1$ & \\
\hline TC NA NF SA & $3 / 3$ & TC SA \\
\hline SM ABP NF SA & $0 / 1$ & \\
\hline KM NA NF SA & $0 / 2$ & \\
\hline CM TC SM NF SA & $0 / 3$ & \\
\hline CM TC KM NF SA & $0 / 3$ & \\
\hline CM TC ABP NF SA & $5 / 7$ & CM TC SA \\
\hline CM TC NA NF SA & $5 / 6$ & CM TC SA \\
\hline TC SM ABP NF SA & $0 / 1$ & \\
\hline TC SM NA NF SA & $0 / 1$ & \\
\hline
\end{tabular}

CM TC SM KM NA SA $1 / 1$

CM TC ABP NA NF SA $0 / 2$

CM TC SM KM SA

\section{TC SM KM ABP NF SA}

$\frac{0 / 1}{\text { Total }} \frac{38 / 168}{\text { a }} \begin{aligned} & \text { Abbreviations: } \mathrm{CM}, \text { chloramphenicol; TC, te- } \\ & \text { tracycline; SM, streptomycin; KM, kanamycin; }\end{aligned}$
ABP, aminobenzyl penicillin; NA, nalidixic acid;
NF, furazolidone; SA, sulfamonomethoxine.

resistant to one, 21 resistant to two, 19 resistant to three, 28 resistant to four, 21 resistant to five, 3 resistant to six and the remaining one was resistant 
$\begin{array}{lllllllllllll}1 & 2 & 3 & 4 & 5 & 6 & 7 & 8 & 9 & 10 & 11 & 12 & 13\end{array}$

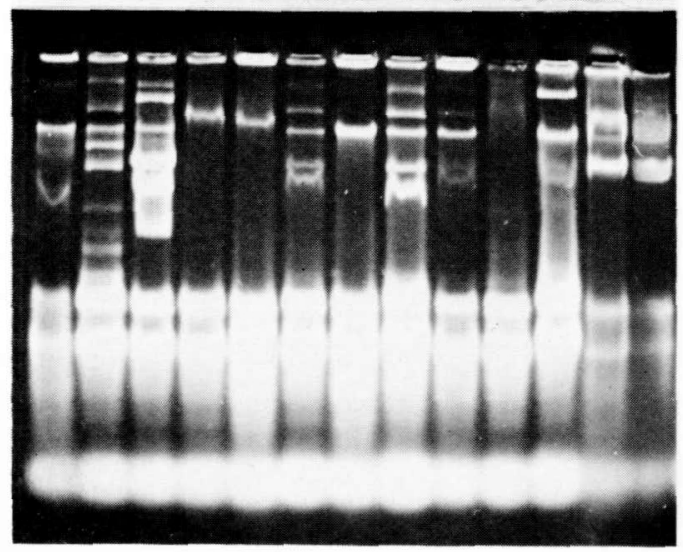

Fig. 2. Agarose gel electrophoresis of plasmid DNAs from 11 strains of Edwardsiella tarda and standard DNA Col K. Cleared lysate was electrophoresed on $0.8 \%$ agarose gels and visualized after ethidium bromide staining. No. 1, TYO46; No. 2, TYO88; No. 3, TYO112; No. 4, T1; No. 5, T33; No. 6, M1; No. 7, M8; No. 8, O1; No. 9, O3; No. 10, K1; No. 11, USA1; No. 12 and No. 12, Col K. Transferable R plasmid was detected in only two strains of No. 1 and No. 3.

to seven drugs. The most common type of the drug resistant strains had the markers of resistance to the combination of $\mathrm{CM}, \mathrm{TC}, \mathrm{NF}$ and/or $\mathrm{SA}$.

Transferable $\mathrm{R}$ plasmids were detected in 38 of 136 resistant strains. The most common type of $\mathrm{R}$ palsmids determined resistances to $\mathrm{CM}$, TC and $\mathrm{SA}$. Other $\mathrm{R}$ plasmids had markers for resistance to TC, SA, TC SA and CM TC SM KM SA. Resistance to NA and NF was not transferred to $E$. coli from any strains of E. tarda.

Electrophoretic patterns in agarose gels of plasmid DNAs of 11 strains of E. tarda are shown in Fig. 2. Transferable $\mathrm{R}$ plasmids were detected in two strains, No. 1 and No. 3, and not detected in other strains. All strains were found to have more than one plasmid and up to eight different plasmid molecules (DNA from No. 2) except transferable $\mathrm{R}$ plasmid.

\section{Discussion}

Incidences of resistant strains of E. tarda in eel culture ponds have been increasing. This increase seems to follow the increase use of chemo- therapeutics in eel culture. Because the resistance markers of E. tarda obtained in this study were $\mathrm{CM}, \mathrm{TC}, \mathrm{NF}$ and/or $\mathrm{SA}$, attention should be paid to the fact that chloramphenicol, tetracycline, nitrofuran derivatives and sulfonamides have been frequently used for the treatment of edwardsiellosis of cultured eel. These drugs are not used so widely in tilapia culture and multiple drug resistant strains of E. tarda were not isolated from tilapia culture ponds. These facts clearly indicate that drug resistant strains of E. tarda have increased in parallel with the increased use of these chemotherapeutics. If these chemotherapeutics are widely used for all fish culture as they were for eel culture pond, it will soon be impossible to treat all infectious bacterial diseases of cultured fish. Fish culturists should not use chemotherapeutics indiscriminately. They should be concerned about a good environment of culture ponds, health of fish and prevention of pathogenic bacteria entering fish farm ponds.

Thirtyeight of 136 drug resistant strains of $E$. tarda isolated from fish culture ponds in various areas were found to carry transferable $\mathrm{R}$ plasmids. Drug resistance markers of the $38 \mathrm{R}$ plasmids detected in E. tarda strains isolated from eel culture ponds were as follows: one, TC, three, SA; twelve, TC SA; twentyone, CM TC SA; and one, CM TC SM KM SA.

In other words, the resistance markers of R plasmids in E. tarda were followed by the chemotherapeutics used for treatment of edwardsiellosis of cultured eel. Incompatibility grouping of part of these plasmids were carried out and all of those $\mathrm{R}$ plasmids were found to be long to group $\mathrm{A}$ as described in a previous paper (AOKI et al., 1977). The origin of the $\mathrm{R}$ plasmids detected in relation to fish culture is not yet known. But since group A R plasmids in E. tarda might not come from enteric bacteria of human and domestic animals, the formation of these $\mathrm{R}$ plasmids could be generated in E. tarda presumably as the results of "transposon" (Calos and Miller, 1980; Starling, 1980).

E. tarda belongs to Enterobacteriaceae and this organism is well known as one of the intestinal flora of snake (SAKAZAKI, 1965) and as a pathogen of man (JoRdAN and HADLEY, 1969). There have been no reports of conjugative $\mathrm{R}$ plasmids of $E$. tarda from snakes and human sources. This fact may also be explained by the abundant use of 
chemotherapeutics for eel culture. Since E. tarda strains isolated from cultured fish directly infect humans and also the $\mathbf{R}$ plasmids can be transferred to human pathogenic bacteria, this could possibility cause a pontential hazard to public health.

Cryptic plasmids were detected in all tested strains of E. tarda. The molecular sizes of these plasmid DNAs was about $10^{8}$ daltons or less. The function of cryptic plasmids detected from E. tarda is not yet known and calls for future investigation.

\section{Acknowledgements}

We are grateful to Dr. Hisatsugu Wakabayashi of Department of Fisheries, Faculty of Agriculture, University of Tokyo and Dr. Yasuhiko Jo of Tokushima Prefectural Experimental Fisheries Station for supplying the materials for this investigation. We would also like to express our apprecation to Mr. Yoshimoto Tanaka and Mr. Akira Akashi of Miyazaki University for their kind assistance. This investigation was supported by a grant from the Japan Fisheries Resources Conservation Association.

\section{References}

Aoki T., T. Arai and S. Egusa (1977): Detection of R plasmids in naturally occurring fish pathogenic bacteria, Edwardsiella tarda. Microbial. Immunol., 21, 77-83.

Calos M. P. and J. H. Miller (1980): Transposable elements. Cell, 20, 579-595.

Crosa J. H., M. H. Schiewe and S. Falkow (1977): Evidence for plasmid contribution to the virulence of the fish pathogen Vibrio anguillarum. Infect. Immun., 18, 509-513.
Jordan G. W. and W. K. Hadley (1969): Human infection with Edwardsiella tarda. Anna. Interna: Medici., 70, 283-288.

Japan Society of Chemotherapy (1975): Methods of minimal inhibitory concentration. Chemotherapy, 23 (8), 1-2 (in Japanese).

Kunugita K. and M. Matsuhashi (1970): Purification and properties of colicin K. J. Bacteriol., 104, 1017-1019.

Kusuda R., T. Itami, M. Munekiyo and H. NaKajima (1977): Characteristics of a Edwardsiella sp. from an epizootic of cultured crimson sea breams. Bull. Japan. Soc. Sci. Fish., 43: 129-134 (in Japanese).

Kusuda R., T. Toyoshima, Y. Iwamura and H. Sako (1976): Edwardsiella tarda from an epizootic of mullets (Mugil cephalus) in Okitsu Bay. Bull. Japan. Soc. Sci. Fish. 42, 271-275 (in Japanese).

Meyer F. P. and G. L. Bullock (1973): Edwardsiella tarda, a new pathogen of channel catfish (Ictalurus punctatus). Appli. Microbio., 25, 155-156.

MiYazaki T. and S. Egusa (1976): Histopathological studies of Edwardsiellosis of the Japanese eel (Anguilla japonica)-III. Elvers and anguillettes. Fish Pathol., 11, 127-131 (in Japanese).

SAKAZAKI R. (1965): A proposed group of the family Enterobacteriaceae, the Asakusa group. Internat. Bull. Bacteriol. Taxono., 15, 45-47.

StaRlinger P. (1980): IS elements and transposons. Plasmid, 3, 241-259.

Wakabayashi H. and S. Egusa (1973): Seasonal changes of bacterial infections among pond-cultured eels (Anguilla japonica). Fish Pathol., 8, 91-97 (in Japanese).

Watanabe T., T. Aoki, Y. Ogata and S. Egusa (1971): $\mathrm{R}$ factors related to fish culturing. Anna. New York Acade. Science., 182, 383-410.

White F. H., C. F. Simpson and L. E. Williams (1973): Isolation of Edwardsiella tarda from aquatic animal species and surface waters in Florida. J. Wildlife Diseas., 9, 204-208. 